\title{
Secondary Immune Deficiency (like Chemoterapy-Induced) Means no Vaccines
}

\author{
Maria Kuman* \\ Holistic Research Institute, USA
}

Submission: August 25, 2018; Published: September 28, 2018

*Corresponding author: Maria Kuman, Holistic Research Institute, 1414 Barcelona Dr., Knoxville, TN 37923; USA, Email: holisticare1@gmail.com

Keywords: Secondary immune deficiency; Chemoterapy; Prolonged usage; Viruses; Immunization; Cancer treatment; Allopathic medicine; Germs; Nonequilibrium theory; Bifurcation point

\section{Editorial}

Secondary immune deficiency is the immune deficiency caused by chemotherapy or other drugs taken for a long time [1]. It should be self-understanding that when the immune system is weakened by chemotherapy or prolonged usage of a drug or drugs, the doctor shouldn't recommend immunizations because if the immune system is weaker, it should not be asked to deal with more and more new viruses, even when these viruses are weakened as they are in the vaccines.

Here is the proof of it. Research was done in Europe with two groups of mice. Both groups were exposed to toxic chemicals. But the second group was also exposed to another stressor. In the first group $27 \%$ of the mice died, in the second group $62 \%$ of the mice died. This means that if the body deals with one stressor (cancer), do not add another stressor the body needs to deal with (like virus from immunization).

I had a friend, who tremendously improved after chemotherapy. However, the doctor-oncologist recommended immunization against pneumonia and when the immunization was done, the cancer came back full blast. Then the doctors did another immunization, this time for flue, and the result was - she didn't need a third immunization because she died. No immunizations should be recommended when the immune system is weak.

I had a British friend, John Biggerstaff, who claimed he has found a substance that boosts the immune system, and this is going to be the next revolution in cancer treatment. But even if substance like this were used as a cancer treatment, I wouldn't recommend the use of immunizations during the course of cancer treatment. Let the body fights with one enemy at a time.

From the $2^{\text {nd }}$ World War we know that Hitler lost the war when the second front on the west was open and he had to fight on two fronts. Based on this experience, we should never allow our body to be forced to fight with another enemy, even when the enemy is not very strong as it is the case with the vaccines. Therefore, vaccines should not be recommended when the body undergoes another treatment.

I recently sent an article for publication in the International Journal of Complimentary and Alternative Medicine [2] explaining how homeopathic remedies work. Our pharmaceutical drugs are called 'allopathic medicine', because they work with the opposite, i.e. they kill the germs. The homeopathic remedies create in the body changes similar to the changes created by the germ.

Nobody could explain how homeopathic remedies cure by creating in the body changes similar to these created by the virus. I did, and I used for this purpose the nonequilibrium theory of Prigogine [3] because each virus shifts our body out of equilibrium. Basic law of this nonequilibrium theory claims that the 'accumulation of quantity always leads to a state with a new quality'.

When this basic rule of the nonequilibrium theory is applied to homeopathy, it means that when the changes created by the homeopathic remedy sum up with the changes created by the virus - a critical level is reached at which the regulation mechanisms of the body kick in, and a new quality of state (state of health) steps in.

The critical point, at which a new quality of state steps in, is called 'bifurcation point'. Mathematically, it means the appearance of a new solution. Medicinally, it means that when this critical point is reached the body is shifted to a new quality of state - the state of health.

I underlined in my article [2] that: if this is the case, the homeopathic remedies would never lead to secondary immune deficiency, as the pharmaceutical remedies do, and this is another advantage of the homeopathic drugs. We need homeopathic remedy for cancer, which will save the patients from the misery of chemotherapy. 


\section{References}

1. Tihoplav V, Tihoplav T, Garmonia Haosa (2003) The Harmony of the Chaos, Russ.

This work is licensed under Creative Commons Attribution 4.0 License

DOI: 10.19080/JCMAH.2018.08.555729
2. Kuman M (2018) International Journal of Complementary and Alternative Medicine 11(5).

3. Prigogine I, Stangers I (1997) The End of Certainty, The Free Press, USA.

Your next submission with Juniper Publishers will reach you the below assets

- Quality Editorial service

- Swift Peer Review

- Reprints availability

- E-prints Service

- Manuscript Podcast for convenient understanding

- Global attainment for your research

- Manuscript accessibility in different formats

( Pdf, E-pub, Full Text, Audio)

- Unceasing customer service

Track the below URL for one-step submission https://juniperpublishers.com/online-submission.php 